\title{
Environmental Disaster Education at University: An Overview in New Normal of COVID-19
}

\author{
Alimun Nasrun A. Hi Alim ${ }^{1, a}$, Henita Rahmayanti ${ }^{1, b^{*}}$, Achmad Husen ${ }^{1, c}$, IImi Zajuli Ichsan ${ }^{1, d}$, \\ Giry Marhento ${ }^{2, e}$, Mashudi Alamsyah',f, Susilo3,g, R. Udhaya Mohan Babu ${ }^{4, h}$, \\ Md. Mehadi Rahman ${ }^{5, i}$ \\ 1Department of Population and Environmental Education, Universitas Negeri Jakarta, Indonesia \\ 2Department of Biology Education, Universitas Indraprasta PGRI, Indonesia \\ ${ }^{3}$ Department of Biology Education, Universitas Muhammadiyah Prof. Dr. Hamka, Indonesia \\ ${ }^{4}$ Department of Education, Alagappa University, India \\ ${ }^{5}$ Institute of Education and Research, University of Dhaka, Bangladesh \\ a mochamadalii@yahoo.com ; b henita.rahmayanti@unj.ac.id ; c ahusen@unj.ac.id; d ilmizajuli95@gmail.com; e girymarhento@gmail.com; \\ f mashudi.alamsyah@gmail.com; 9 susilo@uhamka.ac.id; mohaneducation.1990@gmail.com; ${ }^{\mathrm{h}}$ mehadirahman@gmail.com \\ ${ }^{*}$ Corresponding Author
}

How to Cite: Alim, A.N.A.H., Rahmayanti, H., Husen, A., Ichsan, I.Z., Marhento, G., Alamsyah, M., Susilo, S., Babu, R.U.M., Rahman, M.M. (2020). Environmental Disaster Education at University: An Overview in New Normal of COVID-19. International Journal for Educational and Vocational Studies, 2(8), 714-719. DOI:

https://doi.org/10.29103/ijevs.v2i8.2655

\section{ARTICLE HISTORY}

Received: 2 July 2020

Revised: 20 July 2020

Accepted: 22 July 2020

\section{KEYWORDS}

Disaster Mitigation;

New Normal;

Student Knowledge;

\section{ABSTRACT}

Pandemic Coronavirus Disease (COVID-19) is a non-natural disaster that occurs globally. Disaster mitigation efforts need to be made when entering a new normal life after the physical distancing policy is relaxed. The purpose of this study was to describe the knowledge and participation of students in disaster mitigation activities during the new normal period. The research method used descriptive, data collection techniques through Google Form with a sample of 54 students. The results showed that learning of disaster mitigation education is not maximally taught at the university level with a percentage of $57.4 \%$ for students, who did not receive disaster mitigation education. However, as many as $51.9 \%$ of students had attended training in disaster education. Disaster mitigation education was important to do when a new normal period. That is because students are one component that has a role to convey various information about the disaster, especially COVID-19. This study concludes that knowledge and student participation in disaster education still needs to be improved. The suggestion from this research was necessary to develop innovative learning tools for disaster mitigation education in the new normal era of COVID-19.

This is an open access article under the CC-BY-SA license.

\section{INTRODUCTION}

The geographical location of the country of Indonesia is often hit by natural disasters that often occur in various regions of Indonesia. The countries that are in the location and the ring of fire so it is prone to disasters and causes disasters to occur easily. The level of vulnerability to natural disasters is one of the factors that most influence the occurrence of disasters because new disasters will occur when the Vulnerable Conditions (Pickett et al., 2019; Rachmawati \& Budiarti, 2016). All the people who are probably engaged with disaster situations have a responsibility to develop their capability to prepare, mitigate, respond, and recover. Effective mitigation and preparedness can greatly reduce the threat posed by disasters and post-disaster response will help to reduce the impact of disasters in both the economic and social sectors of a country (Thayaparan et al., 2014). The danger of disaster will also be divided again if the awareness of every citizen is not heeded, the danger of a natural disaster will easily occur because of natural disasters caused by the human activity itself. The disaster that hit shortly is a non-natural disaster, namely Coronavirus Disease (COVID-19).

COVID-19 which occurs in Indonesia even the pandemic in the world. This disaster was a global pandemic that began its spread from the Wuhan, China (Ni et al., 2020; Salzberger et al., 2020; Tian et al., 2020). COVID-19 has rapidly been spreading all over the world and which has made every sector of human life to 
immediately feel its impact (Sintema, 2020). Therefore disasters will occur anytime and anywhere so that the community must always be careful and continue to understand the importance of the participation of Indonesian people in disaster mitigation against the community itself. Disaster mitigation is simply an aspect of disaster planning and management before and after a disaster, known as a disaster management cycle that aims to prevent loss of life and reduce the suffered by humans (Januriyadi et al., 2019; Prabawadhani et al., 2016; Rahmayanti et al., 2020; Shalihati, et al., 2016).

A very important role for the younger generation as well as the community and authorities regarding mitigation education aimed at disaster risk and reducing damage. Disaster mitigation becomes important because if a disaster occurs, the community will certainly lose property and lose economic resources (Berger et al., 2018; Crow \& Albright, 2019). Disaster mitigation itself includes both planning and implementing various actions to reduce risks that have been ignored by many young people, communities, and government. Even though in the pre-disaster stage it is very important because before the disaster has been prepared to minimize the impact of the before and after the disaster.

Disaster mitigation education is very important and needed by young people and the community because there is a Disaster Mitigation program in areas which is very important to do socialization for the community to minimize the impact of disasters (Onuma et al., 2017; Rachmawati \& Budiarti, 2016; Rae, 2016). The level of preparedness and education on environmental disasters for any country and community can influence the extent of the impact of disasters. This reflects the importance to educate university students involved in disaster management activities with the appropriate knowledge and skills. Thus possessing adequate knowledge on disaster management is a key requisite for the younger generation because it will help them to understand the process of mitigation and recovery. As a scientific community and a gathering place for disaster experts, sociologists, geopolitics, doctors and medical personnel, psychologists, economists as well as reconstruction and rehabilitation experts, the role of universities is very important to support the government in disaster management in Indonesia. When entering the new normal era after several months of physical distancing during COVID-19, it is necessary to do innovation and further description of students' understanding of disaster mitigation.

According to the results of research conducted Rahmayanti et al. (2020) which states that the importance of the innovative education model needed in the context of disaster mitigation especially in the COVID-19 pandemic situation. Learning model such as Disaster Mitigation of Flood Based on Online Learning (DIFMOL), it becomes a solving the problem of conventional distance learning difficulties (e-learning) during COVID-19 situations by using descriptive research methods or data collection techniques through Google Form. Based on this, the purpose of this study was to describe the knowledge and participation of students in disaster mitigation activities in the COVID-19 era.

\section{MATERIALS AND METHODS}

This study used a descriptive research design using a survey study approach conducted in June 2020. The descriptive research design which is used in the study aimed to determine the knowledge of students about disaster mitigation education. Data collection was a procedure carried out systematically and standardized to be able to obtain data.

In this regard, based on the type of research and the types of data sources used and those that have been determined, the data collection technique in this study used a questionnaire that will be distributed to 54 respondents. The type of questionnaire that will be given to respondents is a test, which has 15 questions. The data used in this study are primary, that is data obtained directly using descriptive research methods or data collection techniques through Google Form and secondary data, namely data obtained from the results of other people's research or the official website of the property the government and other trusted electronic media.

\section{RESULTS AND DISCUSSION}

In this study, it was found that following the results of data processing research conducted on student knowledge regarding disaster education in college (Campus) is very low. This is evidenced in Table 1 that, the study was conducted with a sample of 54 different students with tertiary level different in all regions of Indonesia have proven that learning disaster mitigation education is not maximally taught in college living with a value of $57.4 \%$ (31 students) and $42.6 \%$ (23 students). Whereas in training and seminars the level of student participation was higher for students to take part in activities in the form of seminars and training on disasters with $51.9 \%$ (28 students) and $48.1 \%$ (26 students). Furthermore, the characteristics of students about disaster simulation activities participated by students in tertiary institutions were also not good because the number $46.3 \%$ (25 students) answered that they had participated in a simulation of disasters while in the figure of $53.7 \%$ (29 students) never followed a simulation about a disaster in college.

The results of this study can also prove that higher education institutions by using a sample of 54 students with different tertiary institutions to prove that disaster mitigation education is not maximally taught on campus. Data showed table 1 that $57.4 \%$ (31 students) never received teaching material on disasters while $42.6 \%$ (23 students) received teaching material on disaster mitigation education. So that the understanding of students about mitigation education is not maximally taught on campus and this is very contrary to the tri dharma of higher education. The knowledge level score for each item for more details can be seen in Table 2. In general, students' knowledge scores still need to be improved to be better. Certainly by providing a lot of education to students about the importance of planning education. 
Table 1. Characteristics of Category Students About Disaster Education

\begin{tabular}{|c|c|c|c|}
\hline No & Characteristics & $f$ & $\%$ \\
\hline \multirow{3}{*}{1} & Gender: & & \\
\hline & Male & 34 & $63 \%$ \\
\hline & Female & 20 & $37 \%$ \\
\hline \multirow{3}{*}{2} & Have you ever had a Disaster-related Subject: & & \\
\hline & Yes & 23 & $42,6 \%$ \\
\hline & No & 31 & $57,4 \%$ \\
\hline \multirow{3}{*}{3} & Have you attended training in disasters: & & \\
\hline & Yes & 28 & $51,9 \%$ \\
\hline & No & 26 & $48,1 \%$ \\
\hline \multirow{3}{*}{4} & Have you ever taken a self-rescue simulation during a Disaster: & & \\
\hline & Yes & 25 & $46,3 \%$ \\
\hline & No & 29 & $53,7 \%$ \\
\hline
\end{tabular}

Table 2. Student Knowledge about Disaster education

\begin{tabular}{|c|c|c|c|c|}
\hline No & & Knowledge level & $f$ & $\%$ \\
\hline \multirow[t]{2}{*}{1} & True & & 45 & $83,3 \%$ \\
\hline & False & & 9 & $16,3 \%$ \\
\hline \multirow[t]{2}{*}{2} & True & & 21 & $38,9 \%$ \\
\hline & False & & 33 & $61,1 \%$ \\
\hline \multirow[t]{2}{*}{3} & True & & 54 & $100 \%$ \\
\hline & False & & 0 & $0 \%$ \\
\hline \multirow[t]{2}{*}{4} & True & & 27 & $50 \%$ \\
\hline & False & & 27 & $50 \%$ \\
\hline \multirow[t]{2}{*}{5} & True & & 44 & $81,5 \%$ \\
\hline & False & & 10 & $17,5 \%$ \\
\hline \multirow[t]{2}{*}{6} & True & & 49 & $40,7 \%$ \\
\hline & False & & 5 & $9,1 \%$ \\
\hline \multirow[t]{2}{*}{7} & True & & 25 & $46,3 \%$ \\
\hline & False & & 29 & $53,7 \%$ \\
\hline \multirow[t]{2}{*}{8} & True & & 50 & $92,6 \%$ \\
\hline & False & & 4 & $7,5 \%$ \\
\hline \multirow[t]{2}{*}{9} & True & & 35 & 64,8 \\
\hline & False & & 19 & $35,2 \%$ \\
\hline \multirow[t]{2}{*}{10} & True & & 28 & $51,9 \%$ \\
\hline & False & & 26 & $48,1 \%$ \\
\hline \multirow[t]{2}{*}{11} & True & & 36 & $66,7 \%$ \\
\hline & False & & 18 & $34,4 \%$ \\
\hline \multirow[t]{2}{*}{12} & True & & 10 & $18,5 \%$ \\
\hline & False & & 44 & $81,4 \%$ \\
\hline \multirow[t]{2}{*}{13} & True & & 26 & $48,1 \%$ \\
\hline & False & & 28 & $51,9 \%$ \\
\hline \multirow[t]{2}{*}{14} & True & & 15 & $27,8 \%$ \\
\hline & False & & 39 & $72,2 \%$ \\
\hline \multirow[t]{3}{*}{15} & True & & 27 & $50 \%$ \\
\hline & False & & 27 & $50 \%$ \\
\hline & Total & & 54 & $100 \%$ \\
\hline
\end{tabular}

Nowadays the education system of the modern world is going through some massive changes (Rahman, 2019). Education is an activity and learning process to develop or increase knowledge, the higher the level of one's education, the better the level of knowledge (Bustami et al., 2018; Cheng \& Monroe, 2012; Chouhan et al., 2017; Sandberg \& Ohman, 2011; Sethusha \& Lumadi, 2013). Conversely the lower level of one's education, the less good the level of knowledge, so that one's education will affect knowledge because in the education process there is a learning process towards something. Including relating to disaster education, in this case, disaster mitigation education becomes an important role to convey various knowledge relating to disaster mitigation. An understanding of disaster mitigation can reduce loss and loss of life (Ramadhan et al., 2019).

Furthermore, the important role of disaster education needs to be developed by universities, especially those in locations or regions prone to disasters. Different methods of training can be used in this regard. Effective training can prevent or reduce the effects of some disasters. Trained people can protect themselves and others better. Therefore, 
the rate of human and financial loss due to disasters is reduced, which is regarded as a prime issue for vulnerable people although it has been less emphasized and there is no comprehensive training program (Torani et al., 2019). Additionally, Disaster education is effective at all stages of the crisis, but its impact is even more in preparation. Therefore, more educational planning should be considered at this stage (Rundmo \& Nordfjærn, 2017). Disaster Education aims to reduce the risk of disasters including the potential for disasters and the history of disasters that have occurred in the region, forms of anticipation, increasing knowledge and awareness of the signs of disasters (Pouyanfar et al., 2019; Sharpe \& Kelman, 2011; Siriwardena et al., 2013; Sutter \& Smith, 2017). Therefore, the campus is also one of the formation areas for agents of change who are character and professional in the context of students' understanding of disaster mitigation education and disaster risk reduction. Furthermore, the campus also has a Tri Dharma College that aims to encourage the creation of campuses and communities that are safe and resilient to disasters.

The role of students and campus residents as agents of change can play an active role in the internal environment of the campus and the community to make awareness efforts about the importance of understanding and good knowledge about disaster mitigation education, especially when entering the new normal era after the COVID-19 pandemic. Students become one of the parties who have an important role in spreading various information about the importance of disaster mitigation because students can move in various fields in the community. Students can also apply various innovations to drive environmental education on campus (Freed, 2018; Ichsan et al., 2020; Jonell et al., 2016; Meyer, 2016).

Disaster mitigation education when entering the new normal era needs to be intensified especially about efforts to reduce the impact of COVID-19. This effort must continue to be done through education regarding COVID-19 prevention efforts. In this study, student knowledge has been measured and showed that students' knowledge scores need to be improved by developing various learning tools. Similarly, Torani et al., (2019) found that Indonesian students have insufficient knowledge about environmental education and disaster management. Therefore, it was suggested that teaching about environmental education and disaster mitigation to students is a very important thing to do to enhance students' understanding and positive attitude towards the environment. The development of this learning tool will have an impact on improving the quality of disaster mitigation education. That is because to improve the ability of disaster mitigation it is necessary to develop various technology-based learning tools (Nissim et al., 2016; Quieng et al., 2015; Seema et al., 2019; Urbani et al., 2017).

\section{CONCLUSION}

Based on the results of the study showed that disaster mitigation education is not maximally taught. Students' knowledge needs to be improved because therefore students are required to take part in activities such as disaster simulations, and seminars and training on disaster preparedness, for example, disaster response sirens and evacuation routes. Suggestions from this research are that in the future, it is necessary to develop various learning tools to support disaster mitigation education efforts at the university level. Besides, it is necessary to carry out a more detailed measurement innovation regarding student skills in disaster mitigation.

\section{REFERENCES}

Berger, E., Carroll, M., Maybery, D., \& Harrison, D. (2018). Disaster Impacts on Students and Staff from a Specialist, Trauma-Informed Australian School. Journal of Child and Adolescent Trauma, 11(4), 521-530. https://doi.org/10.1007/s40653-018-0228-6

Bustami, Y., Syafruddin, D., \& Afriani, R. (2018). The implementation of contextual learning to enhance biology students' critical thinking skills. Jurnal Pendidikan IPA Indonesia, 7(4), 451-457.

https://doi.org/10.15294/jpii.v7i4.11721

Cheng, J. C. H., \& Monroe, M. C. (2012). Connection to nature: Children's affective attitude toward nature. Environment and Behavior, 44(1), 31-49. https://doi.org/10.1177/0013916510385082

Chouhan, S., Bhatnagar, B., Suman, \& Kaur, M. (2017). Assessment of Environmental Attitude of Adolescent of Bikaner City. Studies on Home and Community Science, 11(1), 25-28.

https://doi.org/10.1080/09737189.2017.1336308

Crow, D. A., \& Albright, E. A. (2019). Intergovernmental relationships after disaster: state and local government learning during flood recovery in Colorado. Journal of Environmental Policy and Planning, 21(3), 257-274.

https://doi.org/10.1080/1523908X.2019.1623660

Freed, A. (2018). The relationship between university students' environmental identity, decision-making process, and behavior. Environmental Education Research, 24(3), 474-475.

https://doi.org/10.1080/13504622.2017.1320705

Ichsan, I. Z., Rahmayanti, H., Purwanto, A., Sigit, D. V., Singh, C. K. S., \& Babu, R. U. M. (2020). HOTS-AEP-COVID-19: Students knowledge and digital worksheet of ILMIZI environmental learning model. International Journal of Advanced Science and Technology, 29(6), 5231-5241.

http://sersc.org/journals/index.php/IJAST/article/view/ 19581

Januriyadi, N. F., Yulizar, Y., Pamungkas, R. C., Amru, F., \& Fadhilah, N. (2019). Kajian efektivitas sumur resapan dalam mengurangi resiko bencana banjir di kota jakarta. Seminar Nasional Teknik Sipil 3, 1-7. https://ucs.unud.ac.id/conf/senats-3

Jonell, M., Crona, B., Brown, K., Rönnbäck, P., \& Troell, M. (2016). Eco-labeled seafood: determinants for (blue) green consumption. Sustainability, 8(9), 1-19. https://doi.org/10.3390/su8090884

Meyer, A. (2016). Heterogeneity in the preferences and pro-environmental behavior of college students: The effects of years on campus, demographics, and 
external factors. Journal of Cleaner Production, 112, 3451-3463.

https://doi.org/10.1016/j.jclepro.2015.10.133

Ni, L., Zhou, L., Zhou, M., Zhao, J., \& Wang, D. W. (2020). Combination of western medicine and Chinese traditional patent medicine in treating a family case of COVID-19 in Wuhan. Frontiers of Medicine. https://doi.org/10.1007/s11684-020-0757-x

Nissim, Y., Weissblueth, E., Scott-Webber, L., \& Amar, S. (2016). The Effect of a Stimulating Learning Environment on Pre-Service Teachers' Motivation and 21st Century Skills. Journal of Education and Learning, 5(3), 29. https://doi.org/10.5539/jel.v5n3p29

Onuma, H., Shin, K. J., \& Managi, S. (2017). Reduction of future disaster damages by learning from disaster experiences. Natural Hazards, 87(3), 1435-1452. https://doi.org/10.1007/s11069-017-2825-3

Pickett, N. R., Henkin, S., \& O'Lear, S. (2019). Science, Technology, and Society Approaches to Fieldwork in Geography. Professional Geographer, 1-11. https://doi.org/10.1080/00330124.2019.1639204

Pouyanfar, S., Tao, Y., Tian, H., Chen, S. C., \& Shyu, M. L. (2019). Multimodal deep learning based on multiple correspondence analysis for disaster management. World Wide Web, 22(5), 1893-1911. https://doi.org/10.1007/s11280-018-0636-4

Prabawadhani, D. R., Harsoyo, B., Seto, T. H., \& Prayoga, B. R. (2016). Karakteristik temporal dan spasial curah hujan penyebab banjir di wilayah dki jakarta dan sekitarnya. Jurnal Sains \& Teknologi Modifikasi Cuaca, 17(1), 21-25.

Quieng, M. C., Lim, P. P., \& Lucas, M. R. D. (2015). 21st Century-based Soft Skills: Spotlight on Non-cognitive Skills in a Cognitive-laden Dentistry Program. European Journal of Contemporary Education, 11(1), 72-81. https://doi.org/10.13187/ejced.2015.11.72

Rachmawati, R., \& Budiarti, C. V. (2016). Use of space and the need for planning in the disaster-prone area of code river, yogyakarta, indonesia. Indonesian Journal of Geography, 48(2), 178-190.

https://doi.org/10.22146/ijg.17633

Rae, A. (2016). Tales of disaster: the role of accident storytelling in safety teaching. Cognition, Technology and Work, 18(1), 1-10.

https://doi.org/10.1007/s10111-015-0341-3

Rahman, M. M. (2019). 21st Century Skill "Problem Solving": Defining the Concept. Asian Journal of Interdisciplinary Research, 2(1), 64-74.

https://doi.org/10.34256/ajir1917

Rahmayanti, H., Ichsan, I. Z., Azwar, S. A., Oktaviani, V., Ladesi, V. K., \& Pertiwi, N. (2020). Garbage Sorting Games, DIFMOL, and ILMIZI: Technology Innovation for Environmental Learning of Disaster Mitigation. International Journal of Advanced Science and Technology, 29(5), 11255-11265.
http://sersc.org/journals/index.php/IJAST/article/view /25221

Ramadhan, S., Sukma, E., \& Indriyani, V. (2019). Environmental education and disaster mitigation through language learning. IOP Conf. Series: Earth and Environmental Science, 314.

https://doi.org/10.1088/1755-1315/314/1/012054

Rundmo, T., \& Nordfjærn, T. (2017). Does risk perception really exist? Safety Science, 93, 230-240. https://doi.org/10.1016/j.ssci.2016.12.014

Salzberger, B., Glück, T., \& Ehrenstein, B. (2020). Successful containment of COVID-19: the WHO-Report on the COVID-19 outbreak in China. Infection, 48, 151-153. https://doi.org/10.1007/s15010-020-01409-4

Sandberg, K. W., \& Ohman, G. (2011). Learning in innovation development. Procedia - Social and Behavioral Sciences, 28, 379-383.

https://doi.org/10.1016/j.sbspro.2011.11.072

Seema, S., Gupta, M., \& Sharma, R. K. (2019). 21st century skills and sustainability. International Journal of Advanced Science and Technology, 28(16), 507-513.

Sethusha, M. J., \& Lumadi, M. W. (2013). Grade Six Learners' Perceptions of Environmental Awareness: A Human Ecological Support Programme. Journal of Human Ecology, 42(2), 113-123.

https://doi.org/10.1080/09709274.2013.11906585

Shalihati, S. F., Hadi, P., \& Widiyastuti, M. (2016). Sistem perdagangan risiko bencana dalam pengelolaan banjir antar-wilayah. Majalah Geografi Indonesia, 24(1), 26-35. https://doi.org/10.22146/mgi.13339

Sharpe, J., \& Kelman, I. (2011). Improving the disaster-related component of secondary school geography education in England. International Research in Geographical and Environmental Education, 20(4), 327-343.

https://doi.org/10.1080/10382046.2011.619810

Sintema, E. J. (2020). Effect of COVID-19 on the performance of grade 12 students: implications for STEM education. Eurasia Journal of Mathematics, Science and Technology Education, 16(7), 1-6. https://doi.org/10.29333/ejmste/7893

Siriwardena, M., Malalgoda, C., Thayaparan, M., Amaratunga, D., \& Keraminiyage, K. (2013). Disaster resilient built environment: role of lifelong learning and the implications for higher education. International Journal of Strategic Property Management, 17(2), 174-187.

https://doi.org/10.3846/1648715X.2013.806373

Sutter, D., \& Smith, D. J. (2017). Coordination in disaster: Nonprice learning and the allocation of resources after natural disasters. Review of Austrian Economics, 30(4), 469-492.

https://doi.org/10.1007/s11138-016-0369-5 
Thayaparan, M., Malalgoda, C., Keraminiyage, K., \& Amaratunga, D. (2014). Disaster management education through higher education-industry collaboration in the built environment. Procedia Economics and Finance, 18, 651-658.

https://doi.org/10.1016/S2212-5671(14)00987-3

Tian, S., Hu, N., Lou, J., Chen, K., Kang, X., Xiang, Z., Chen, H., Wang, D., Liu, N., Liu, D., Chen, G., Zhang, Y., Li, D., Li, J., Lian, H., Niu, S., Zhang, L., \& Zhang, J. (2020). Characteristics of COVID-19 infection in Beijing. Journal of Infection, 80(4), 401-406. https://doi.org/10.1016/j.jinf.2020.02.018

Torani, S., Majd, P. M., Maroufi, S. S., Dowlati, M., \& Sheikhi, R. A. (2019). The importance of education on disasters and emergencies: A review article. Journal of Education and Health Promotion, 85(8). https://doi.org/10.4103/jehp.jehp_262_18

Urbani, J. M., Truesdell, E., Urbani, J. M., Roshandel, S., Michaels, R., \& Truesdell, E. (2017). Developing and Modeling 21st-Century Skills with Preservice Teachers. Teacher Education Quarterly, 44(4), 27-51. https://www.jstor.org/stable/90014088?seq=1 